Article

\title{
Public Participation in Water Planning in the Ebro River Basin (Spain) and Tucson Basin (U.S., Arizona): Impact on Water Policy and Adaptive Capacity Building
}

\author{
Alba Ballester ${ }^{1, *}$ and Kelly E. Mott Lacroix ${ }^{2}$ \\ 1 Institut de Govern i Polítiques Públiques, Universitat Autònoma de Barcelona, Campus UAB-Edifici MRA, \\ Bellaterra 08193, Spain \\ 2 Water Resources Research Center, University of Arizona, 350 N Campbell Ave, Tucson, AZ 85719, USA; \\ klacroix@email.arizona.edu \\ * Correspondence: alba.ballester@gmail.com or Alba.Ballester@uab.cat; Tel.: +34-628-443-001 \\ Academic Editors: Eylon Shamir, Sharon B. Megdal and Susanna Eden \\ Received: 21 February 2016; Accepted: 20 June 2016; Published: 29 June 2016
}

\begin{abstract}
The benefits of public participation in water management are recognized by governments, scholars, and stakeholders. These benefits, however, do not result from all engagement endeavors. This leads to the question: What are the determinants for effective public participation? Given a list of criteria for achieving the transformational capacity of participation, we analyze the benefits (including the influence on public policies) gained through public participation and the determinant factors for obtaining these benefits in the Ebro River Basin in Spain and in the Tucson Basin in Arizona (U.S.). Furthermore, and considering that droughts and floods are major water management challenges in both case studies, we focus on the potential of participation to build adaptive capacity. Our analysis of these case studies concludes that influence on public policies is determined more by the context of the participatory process, i.e., legal framework, political leadership, and social awareness, whereas influence on adaptive capacity building depends more on the characteristics of the participatory process, particularly the existence of active on-site consultation and deliberation.
\end{abstract}

Keywords: water management; public participation; stakeholder engagement; adaptive capacity

\section{Introduction}

Water is a collective heritage with different functions, uses, and values. Water is also finite, vulnerable to contamination and the effects of climate variability, which makes its future availability uncertain. Governments and scholars alike note that decision-making for water should be through a collaborative and inclusive process, where all the voices are represented [1-3]. This recognition is reflected in requirements for public participation in different treaties and laws, particularly in natural resource management (i.e., [4-7]). Public participation is defined here as the process through which citizens seek to influence public issues [8]. The opportunities for input can be embedded within or outside of institutions, and occur with different degrees of public influence on a process. Most categorizations of public participation range from degrees of non-participation (manipulation), apparent participation (information, consultation, active involvement), to citizen power (management, decision) $[9,10]$.

Over the past two decades, many participatory processes for water resource planning have been developed, and research about the implementation of this participation and its benefits has grown considerably (Table 1). 
Table 1. Benefits of public participation.

\begin{tabular}{cc}
\hline Benefit & Citations \\
\hline Building social capital, trust, and mutual respect & {$[11-13]$} \\
Anticipating conflict and overcoming historical tensions & {$[14]$} \\
Improving capacity to achieve collaborative agreements & {$[12,15]$} \\
Increasing the autonomy of individuals and communities & {$[16]$} \\
Permitting access to information & {$[17,18]$} \\
Fostering social learning and understanding of issues & {$[19-25]$} \\
Improving the efficiency of plan implementation & {$[26-28]$} \\
Increasing the legitimacy and quality of decisions & {$[29]$} \\
Increasing community cohesion and collective identity & {$[24,25]$} \\
\hline
\end{tabular}

These benefits are not, however, inherent to all participatory experiences. Frequently, public participation does not influence final decisions, improve knowledge or relationships that could impact the quality of decisions, or achieve the objectives of the participation process [20,30]. When these benefits do not manifest, what is the cause? Or conversely, what elements must a process have to reap the well-noted benefits of public participation? Many authors have highlighted the importance of procedural features of the participatory processes while others have focused on the importance of the context in which participation occurs (e.g., [3,31-33]). As a result of both lines of thought, Blanco and Ballester [34] identified five conditions for improving participation's transformational capacity: (1) political leadership of the participatory process and the affected resulting policies [35]; (2) a holistic approach to collective problems [36]; (3) a highly visible engagement process [37]; (4) significant citizen impact on public policies through the participatory process $[9,38]$; and (5) a real cultural change of politicians, bureaucrats, and citizens $[39,40]$.

It is notable that the potential benefits of public participation coincide with the determinants of adaptive capacity. Adaptive capacity is the ability of a system to adjust, modify or change its features or actions to moderate potential damages, take advantage of opportunities, or cope with the consequences of shock or stress [41,42]. Despite a lack of agreement on the characteristics and determinants of adaptive capacity at different levels, general determinants of adaptive capacity can be found in the literature related to water issues (e.g., [43-45]). The Intergovernmental Panel on Climate Change groups these characteristics into three categories: economic development, technology, and social factors. Focusing on the social dimension of adaptive capacity, we identify three core aspects related to human, social, and political capital: knowledge, networks, and governance respectively (Table 2). Although different studies have linked public participation with adaptive capacity, and consider participation as a key factor in it [46-48], the relationship between how public participation contributes to adaptive-capacity building remains relatively unexplored empirically.

To further understanding of the potential that public participation has to increase adaptive-capacity in water management, we evaluated two case studies, Ebro River Basin in Spain and the Tucson Basin in the U.S. state of Arizona, based on the framework identified in Blanco and Ballester [34] for determining the transformational capacity of a public process. For each case study we explored the connections between participation and adaptive capacity by examining the context, process, and outcomes of public participation in light of the following questions: (1) To what extent does the legal, institutional, political, and social context of participation and the participatory process influence the results of participation; and (2) What impact does the participatory processes have on public policies and adaptive capacity building? 
Table 2. Relationship between social factors of adaptive capacity and benefits of public participation.

\begin{tabular}{|c|c|}
\hline Social Factors of Adaptive Capacity & Benefits of Public Participation \\
\hline $\begin{array}{l}\text { - } \quad \text { Knowledge (Human Capital); } \\
\text { - } \quad \text { responses to socio-ecological systems; } \\
\text { - } \quad \text { React to those changes in a timely appropriate } \\
\quad \text { way [49]; } \\
\text { - Permit well-informed decisions on } \\
\text { adaptation [50]. }\end{array}$ & $\begin{array}{l}\text { - Permitting access to information and } \\
\text { social learning; } \\
\text { - Increasing public capacity and understanding } \\
\text { of issues; } \\
\text { - Co-creation of knowledge. }\end{array}$ \\
\hline $\begin{array}{l}\text { - } \quad \text { Networks (Social capital); } \\
\text { - } \quad \text { Permits quicker and effective response against } \\
\text { change }[45,51] .\end{array}$ & $\begin{array}{l}\text { - } \quad \text { Building social capital, trust, mutual respect; } \\
\text { - Increasing the autonomy of individuals } \\
\text { and communities; } \\
\text { Increasing community cohesion and } \\
\text { collective identity. }\end{array}$ \\
\hline $\begin{array}{l}\text { - } \quad \text { Governance (Political capital); } \\
\text { Access to a greater diversity of knowledge } \\
\text { Increased transparency, accountability, equity, } \\
\text { and trust in water governance systems. [52-55] }\end{array}$ & $\begin{array}{l}\text { - Anticipating conflict and overcoming historical } \\
\text { tensions Improving capacity to achieve } \\
\text { collaborative agreements; } \\
\text { - Increasing the legitimacy and quality } \\
\text { of decisions; } \\
\text { - Improving efficiency of plan implementation. }\end{array}$ \\
\hline
\end{tabular}

\section{Materials and Methods}

\subsection{Case Studies}

This study is a part of the Sustainable Water ActioN (SWAN) project, whose primary objective is the exchange of knowledge among researchers in the United States and European Union on water management issues. This partnership provided the authors with the opportunity to jointly analyze the stakeholder engagement in water planning in the Ebro River Basin and the Tucson Basin. This assessment is focused on participation in the First River Basin Management Plan (RBMP) of the Ebro Basin after the approval of the Water Framework Directive (WFD), and the Third Management Plan of the Tucson Active Management Area (TAMA) (Figure 1).

The Ebro River is the largest in Spain in terms of volume of water discharged, with an annual average flow of $14,623 \mathrm{hm}^{3}$, and a total water demand of $8184 \mathrm{hm}^{3}$. Despite this apparent abundance, the continued growth of demands and Ebro's marked drought periods have caused regular periods of scarcity. Late 20th century land-use regulations have not been expediently implemented, i.e., delimitation of flood-prone areas was required in the 1985 "Ley de Aguas", but floodplains were not mapped until very recently, after 2007s European Floods Directive. Together with hydrological variability, this has caused high flood risk along large areas of the Ebro River's main stem, which affects both agricultural uses and urban sites.

Water use is divided into four sectors: $98 \%$ for irrigation (mainly) and farming; $2 \%$ for urban supply; $>1 \%$ for livestock, and $>1 \%$ for industrial uses [56]. The total population of the Ebro Basin in 2013 was 3,226,921 inhabitants, which are unevenly distributed across an area of $85.362 \mathrm{~km}^{2}$ : The population is concentrated in 5 large cities, representing $50 \%$ of the total population.

The Ebro River is considered to be a "transfer" basin, meaning that water is removed from it to other basins. At this time just $1 \%$ of annual average flow is transferred out of the basin, however, various inter-basin transfers, constituting up to $10 \%$ of annual average flow, have been recently proposed. 

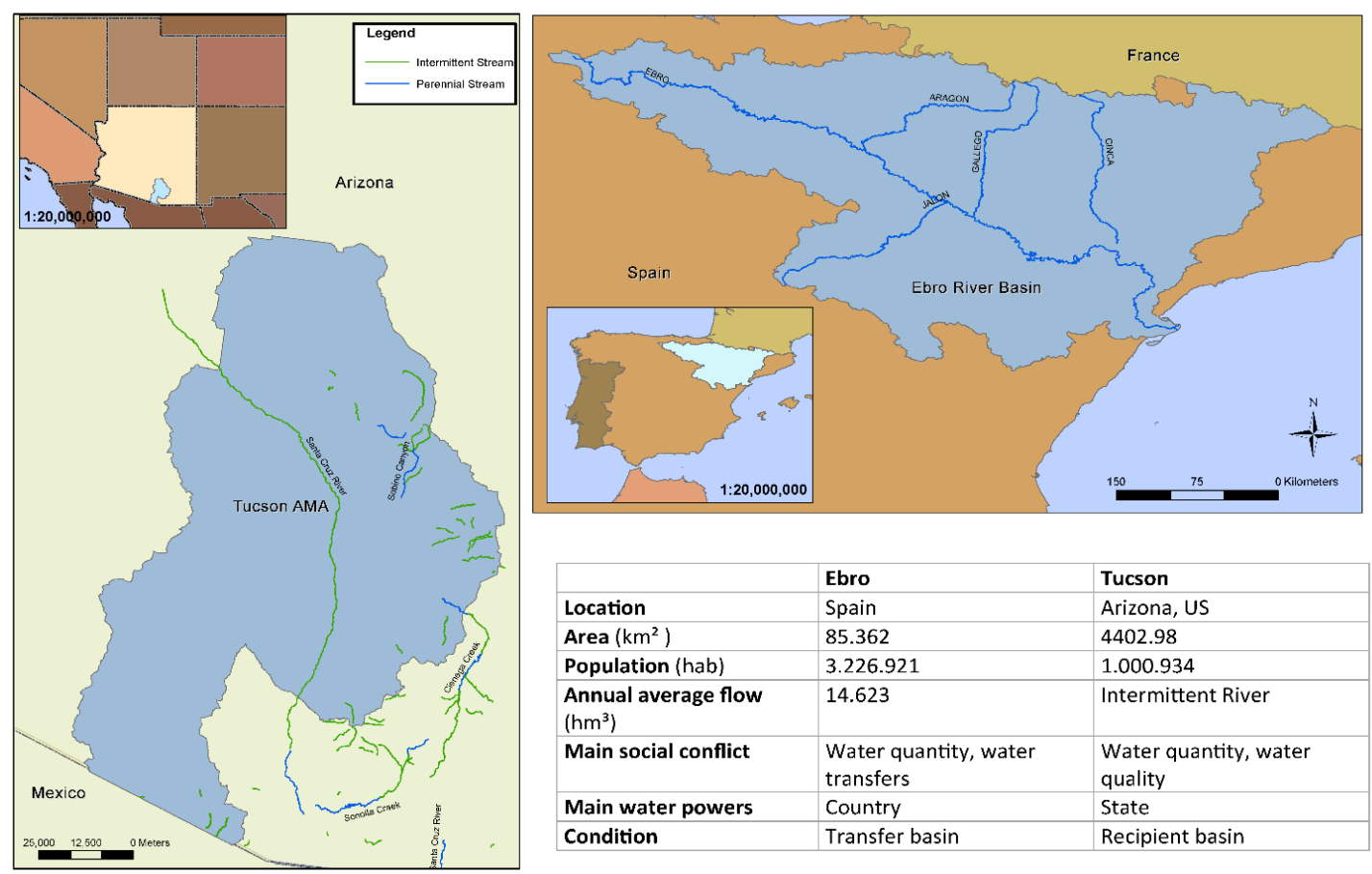

Figure 1. Case study areas and key aspects.

Tucson Basin's primary river, the Santa Cruz, is an intermittent stream. Although sections of the Santa Cruz River have always been intermittent, historically there were perennial reaches where groundwater always met the surface [57]. The current drought, while not uncommon historically, has exacerbated water supplies [58] and growth in the urban areas has contributed to the risk of scarcity [59].

The population of the Tucson Basin in 2013 was approximately 1,000,000. Of this population, 53\% live in the City of Tucson. Aside from Tucson, there are four other cities with populations greater than 20,000. While population is one-third the one in the Ebro Basin, total water demand is as much as 20 times smaller than in the Ebro Basin with $421 \mathrm{hm}^{3}$ in 2013. This demand is distributed as $48 \%$ for urban supply; $32 \%$ for farming and ranching; $14 \%$ for industry; and $5 \%$ for Native American tribes. These demands are met by groundwater (50\%), imported water from the Colorado River via Central Arizona Project (CAP) (38\%), and reclaimed water (14\%). It is notable that in 1985 the water supply of the basin was $99 \%$ groundwater [60].

Despite their different scales, water uses, and population, the Ebro River and Tucson Basin have and will continue to face similar water management challenges, which means that building adaptive capacity is and will be an issue of great importance. Besides this, participatory processes under diverse legislation, social and cultural patterns, have occurred in each of the basins to try to cope with the aforementioned challenges. A comparative analysis of the cases contributes to an understanding of the factors that may encourage adaptive-capacity building within a participatory process.

\subsection{Methods}

The methods are designed to answer the aforementioned questions: (1) To what extent does the context of participation and the participatory process influence the results of participation; and (2) What impact does the participatory processes have on public policies and adaptive capacity building? To answer these questions we examined (1) the legal, political, and social context of participation; (2) the nuts and bolts of the participatory process; and (3) outcomes of participation. A detailed description of the context and process are provided in Table 3. 
Table 3. Context and process aspects and study questions.

\begin{tabular}{lll}
\hline Variable & Aspects & Questions \\
\hline \multirow{2}{*}{ Context } & Political leadership & $\begin{array}{l}\text { Does the convener provide the resources necessary for } \\
\text { effective participation? Is the participatory process central } \\
\text { to water planning decisions? }\end{array}$ \\
\cline { 2 - 3 } & Social awareness & $\begin{array}{l}\text { Is there any conflict associated with the participatory } \\
\text { process? Are there any social movements specifically } \\
\text { devoted to the reason of the participatory process? }\end{array}$ \\
\hline Objectives & $\begin{array}{l}\text { What are the objectives of the participatory process? Were } \\
\text { these objectives clearly outlined for the participants? }\end{array}$ \\
\cline { 2 - 3 } Process & $\begin{array}{l}\text { How many participants were there? } \\
\text { Pid the participants represent diverse water interests and } \\
\text { perspectives? }\end{array}$ \\
\cline { 2 - 3 } & Meetings & $\begin{array}{l}\text { How many meetings have been organized? Was there } \\
\text { sufficient time for deliberation? }\end{array}$ \\
\cline { 2 - 3 } & Consultation & Was participation in person or remote? \\
\hline Methods & $\begin{array}{l}\text { What methods of outreach and engagement were used? } \\
\text { (e.g., written, conferences, round table, deliberation) }\end{array}$ \\
\hline Visibility & Was the process widely visible for general public? \\
\hline
\end{tabular}

The outcome of participation's impact on public policy was straightforward: Did the participation change the policy? For adaptive capacity, however, it was necessary to take a more detailed approach. For the adaptive capacity outcomes, we propose a list of indicators based on the adaptive management literature. To build these indicators, we started with the social dimensions of adaptive capacity (knowledge, networks, and governance) and then developed indicators based on the elements of a process associated with increasing or improving knowledge, networks, and governance [48-55]. For each indicator we have defined a list of key research questions to be answered (Table 4).

Methods and data used for this study include: (1) analysis of documents related to the two participatory processes: minutes, planning documents, and previous research related to the case studies [8,61,62]; and (2) qualitative data obtained through 18 interviews with key stakeholders who actively participated in either the Ebro or Tucson basin participatory processes (Table 5). Of the interviews, 14 are from participants in the Ebro Basin and 4 are from the Tucson Basin. While the number of interviewees from the Tucson Basin is small, we were able to rely on a previous study [62] that interviewed a broad set of stakeholders about the planning process for the Third Management Plan to supplement our information. For the Ebro process, the author was a facilitator for recreational users at the basin scale, and participated in other plan-related meetings, while for the Tucson process the author was not involved in any part of the process. 
Table 4. Outcomes: Indicators and study questions.

\begin{tabular}{|c|c|c|c|c|}
\hline Variable & Aspect & \multicolumn{2}{|l|}{ Indicators } & Questions \\
\hline \multirow{8}{*}{ Outcomes } & $\begin{array}{l}\text { Impact on public } \\
\text { policies }\end{array}$ & \multicolumn{2}{|c|}{$\begin{array}{l}\text { Existence of minor or major revisions or changes in } \\
\text { the final plan: } \\
\text { (1) Minor: The incorporation of measures that usually } \\
\text { are widely agreed upon and do not require a } \\
\text { significant investment in time or money. } \\
\text { (2) Major: The incorporation of substantive changes } \\
\text { in the approach to water management, or the } \\
\text { incorporation of relevant and sensitive measures in } \\
\text { water planning (i.e., environmental flows, revision of } \\
\text { agricultural water concessions, link to urban } \\
\text { development, etc.). }\end{array}$} & $\begin{array}{l}\text { Did public participation } \\
\text { change the final plan } \\
\text { or policy? }\end{array}$ \\
\hline & \multirow{7}{*}{$\begin{array}{l}\text { Impact on adaptive } \\
\text { capacity building }\end{array}$} & Learning & $\begin{array}{l}\text { Existence of learning, both } \\
\text { in water authorities and } \\
\text { the public }\end{array}$ & $\begin{array}{l}\text { Was the participation a } \\
\text { learning process? }\end{array}$ \\
\hline & & Knowledge & Generate new knowledge & $\begin{array}{l}\text { Did it generate any new } \\
\text { knowledge? }\end{array}$ \\
\hline & & Collective vision & $\begin{array}{l}\text { Reach collective vision, the } \\
\text { transformation of private } \\
\text { interests to a collective } \\
\text { public vision }\end{array}$ & $\begin{array}{l}\text { Did the participants change } \\
\text { their perspective on key } \\
\text { issues? Did the process } \\
\text { permit to transform private } \\
\text { interests into a public } \\
\text { position that incorporates a } \\
\text { collective perspective? }\end{array}$ \\
\hline & & Willingness & $\begin{array}{l}\text { Gain willingness to be } \\
\text { involved in public issues }\end{array}$ & $\begin{array}{l}\text { Did participation impact on } \\
\text { the public's willingness to } \\
\text { be involved in water issues } \\
\text { and collaborate with } \\
\text { other groups? }\end{array}$ \\
\hline & & Networks & $\begin{array}{l}\text { Improve networks } \\
\text { between stakeholders } \\
\text { Existence of lasting } \\
\text { groups emerging from } \\
\text { the process }\end{array}$ & $\begin{array}{l}\text { What impact did the } \\
\text { process have on } \\
\text { communication } \\
\text { among water } \\
\text { interest groups? } \\
\text { Where there any } \\
\text { lasting groups, } \\
\text { associations or } \\
\text { networks that } \\
\text { emerged from } \\
\text { the process? }\end{array}$ \\
\hline & & Trust & $\begin{array}{l}\text { Increased trust among the } \\
\text { involved stakeholders and } \\
\text { practitioners }\end{array}$ & $\begin{array}{l}\text { What impact did the } \\
\text { process have on trust } \\
\text { among water community? }\end{array}$ \\
\hline & & Continuity & $\begin{array}{l}\text { Continuity of the process in } \\
\text { subsequent planning cycles }\end{array}$ & $\begin{array}{l}\text { Are new planning efforts } \\
\text { improving public } \\
\text { participation? }\end{array}$ \\
\hline
\end{tabular}

Table 5. Interviewees profile in Ebro and Tucson basins.

\begin{tabular}{ccc}
\hline Stakeholder Type & Ebro & Tucson \\
\hline Recreation & 3 & \\
Environment & 3 & 2 \\
State government & 1 & 1 \\
Agriculture & 2 & \\
Facilitator & 2 & 1 \\
Municipal government & 2 & \\
Power generation & 1 & \\
\hline
\end{tabular}




\section{Results}

\subsection{Context}

\subsubsection{Legal and Institutional Framework}

The legal and institutional frameworks that establish water management process and public involvement in Ebro and Tucson basins are distinct. Though some aspects of the frameworks are not directly applicable to the case studies, we examined the complete framework to gain insight into the overall context in each basin and its potential to influence participatory outcomes in each basin. One difficulty in contrasting the basins is that the management scales do not coincide. Theoretically, the comparison between the two should be at the country level, i.e., Spain vs. U.S. In practice, however, the regulatory framework of water management is first established at European and U.S. levels. For this reason, our analysis begins at the geographic scope of the United States and the European Union (Figure 2).

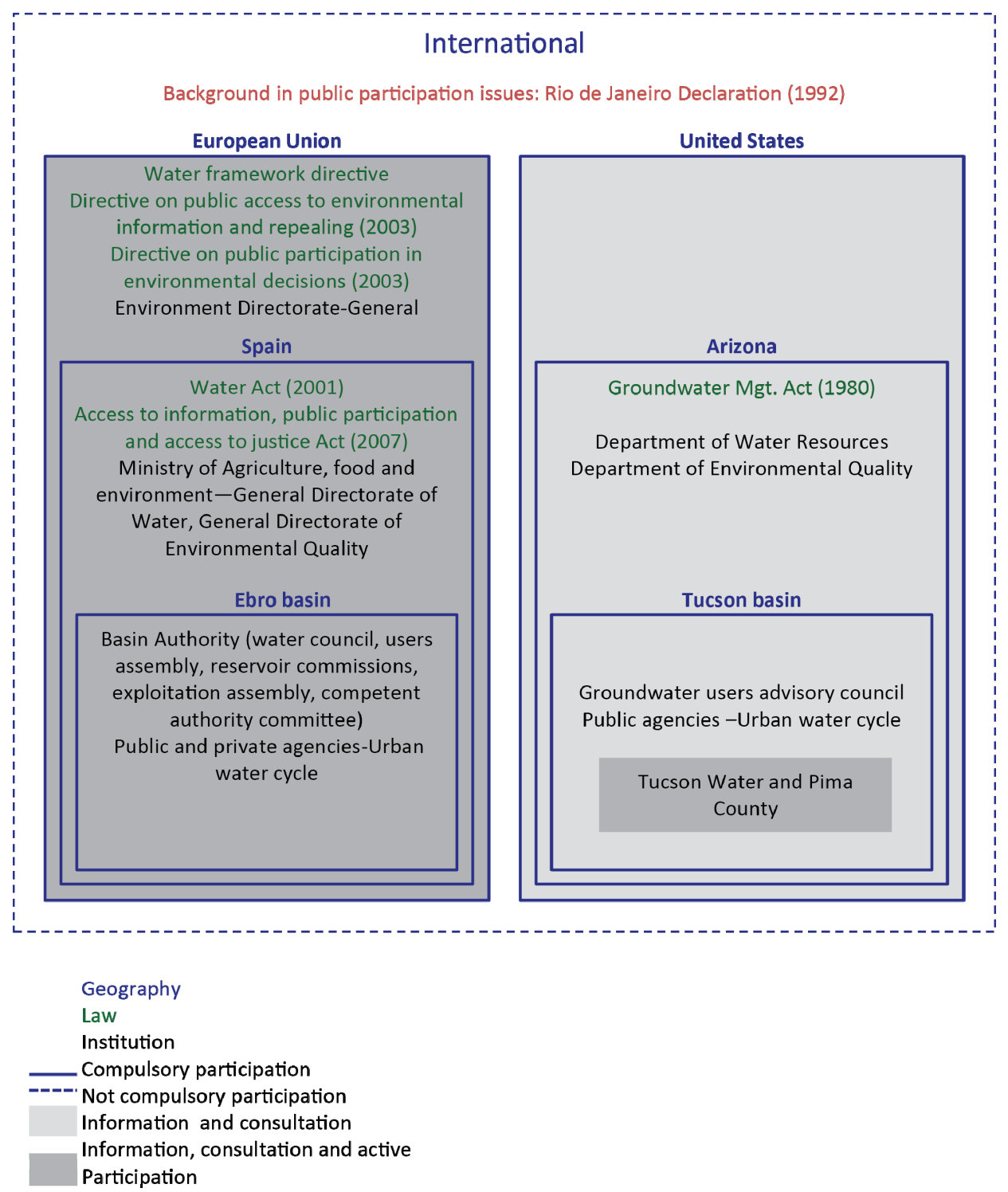

Figure 2. Legal and institutional frameworks for water management and public participation in Ebro and Tucson basins. 
The European Union adopts regulations, directives, and decisions that apply to all EU Member States, which prevail over the rules of individual Member States. Since 2000, the main legislation applicable to water is the WFD (2000/60/EC), which is premised on ecosystems protection, sustainable use of water, and public participation. In accordance with these principles, the WFD establishes one main objective for water policy: The good ecological status (ecological, quantitative and chemical) of water bodies by 2015. To achieve this goal there are a suite of tools: Water planning, programs of measures, and monitoring programs [16].

Spain is politically divided into seventeen regional governments (autonomous communities) with large political, economic, and administrative capabilities. Spanish water management is decentralized, and authority is distributed between national, autonomous communities, and local administrations. Water planning is organized through 18 river basins, nine of them are intercommunity basins under national authority; seven are intracommunity basins, under autonomous competences; and two special cases correspond to the independent cities of Ceuta and Melilla, which are located in Northern Africa [63]. Each basin has its own water authority, called a River Basin Organization (RBO) in the basins that belong to the nation, and Water Agencies in the basins that belong to an Autonomous Community. Each basin authority is responsible for developing a River Basin Management Plan, which is reviewed by the National Water Council, an advisory body ascribed to the Ministry of Environment, and approved by Council of Ministries.

The Ebro River Basin is an intercommunity basin under national control. It has a governing board (Water Council) formed by representatives of national and RBO administrations, all regional administrations from within the basin, and some supra-local administrations. It also includes representatives of water users, and more recently, other water stakeholders that are invited by the RBO. Traditionally, representation of water users has been proportional to the amount of water allocated [63]. As noted before, agriculture uses over $90 \%$ of the water concessions in the region, therefore agricultural users traditionally have had more influence than others on the governing board and therefore in the decision-making process. The approval of WFD has required a more open participation that goes beyond the traditional users to include all stakeholders and the general public.

The legal framework for public participation in environmental matters in Europe is regulated by the Aarhus Convention (1998) and by the WFD. The particular obligations of public participation in water policy are regulated through article 14 of WFD: "Member States shall encourage the active involvement of all interested parties in the implementation of this Directive, in particular in the production, review and updating of the river basin management plans...". Within this context information supply and consultation are ensured and active involvement is encouraged [64].

In the U.S., water quantity is regulated on a state-by-state basis, and many states do not have laws regulating water quantity. Water quality, on the other hand, is regulated through the Clean Water Act, which is either administered by the Environmental Protection Agency (EPA) or through a statewide water quality agency for whom the EPA has delegated authority. Water management in the Tucson Basin is at the state and local levels via the Arizona Department of Water Resources (ADWR), county, and local jurisdictions. Regional water management is through the Tucson Active Management Area (AMA), which is part of ADWR. The regulatory framework is at the state level and results in (1) strict regulation of groundwater pumping; (2) requirements for renewable water supplies; and (3) achievement of "safe-yield" of the aquifer by 2025 [65].

Arizona is often cited for its forward thinking regulation of groundwater in the populous portions of the state through the 1980 Groundwater Management Act (GMA) [62,66]. Public participation in the GMA (ARS 45-420) management plan process consists of public hearings to review all draft management plans prior to approval. There are no other provisions for public participation. The GMA does, however, establish a groundwater user's advisory council (GUAC) in each basin (referred to as active management areas (AMAs)) that consists of five members appointed by the governor of Arizona "on the basis of their knowledge of, interest in and experience with problems relating to the development, use and conservation of water". The role of the GUAC is to: "Advise the area director 
for the active management area, make recommendations on groundwater management programs and policies for the active management area and comment to the area director and to the director on draft management plans for the active management area before they are promulgated by the director". In addition, "Provide comment to the Arizona water banking authority with regard to draft plans for additional storage facilities and draft plans of operation in accordance with sections 45-2453 and 45-2456". Finally, although more generally applicable, citizens in Arizona have the ability to refer issues to the ballot, through collecting signatures equal to $5 \%$ of the registered voters in the jurisdiction where the election will be held. Draft plans for the Arizona water banking authority are provided for public comment each year and citizen ballot initiatives are common. Most notably is a 1990s citizen initiative that restricts how water from the CAP canal is delivered to Tucson residents.

Examining the two cases side by side (Table 6), there is more specific legal framework on public participation in water policy in European Union, which is especially true when compared to the federal level in the United States. For example, the Groundwater Management Act does not mention active involvement, whereas active involvement is included in the EU Water Framework Directive.

Table 6. Comparison of case studies legal frameworks.

\begin{tabular}{|c|c|c|c|c|c|c|}
\hline & Main Laws & $\begin{array}{l}\text { Relevance of } \\
\text { Participation }\end{array}$ & $\begin{array}{l}\text { Participation } \\
\text { Degree }\end{array}$ & $\begin{array}{c}\text { Degree of } \\
\text { Obligation }\end{array}$ & Public Involved & $\begin{array}{l}\text { Participation } \\
\text { Timing }\end{array}$ \\
\hline \multirow[t]{2}{*}{ Ebro Basin } & \multirow{2}{*}{$\begin{array}{l}\text { European } \\
\text { Water } \\
\text { Framework } \\
\text { Directive }\end{array}$} & \multirow{2}{*}{$\begin{array}{l}\text { Considered a } \\
\text { Principle of } \\
\text { Water } \\
\text { Management }\end{array}$} & $\begin{array}{l}\text { Information } \\
\text { and } \\
\text { Consultation }\end{array}$ & $\begin{array}{l}\text { Must be } \\
\text { ensured }\end{array}$ & $\begin{array}{l}\text { General public \& } \\
\text { stakeholders }\end{array}$ & \multirow[t]{2}{*}{$\begin{array}{c}\text { Whole } \\
\text { planning cycle }\end{array}$} \\
\hline & & & $\begin{array}{c}\text { Active } \\
\text { involvement }\end{array}$ & $\begin{array}{c}\text { Must be } \\
\text { encouraged }\end{array}$ & Stakeholders & \\
\hline
\end{tabular}

\subsubsection{Political Leadership}

The Ebro RBO is responsible for implementing the public participation process during the elaboration, review, and implementation of RBMP. Thus, public participation during the first planning cycle after WFD was funded through the basin organization (national funding), and promoted through the Hydrological Planning Office, which is in charge of the elaboration of the RBMP. The Hydrological Planning Office did not have any experience with a public participation process, were not devoted to the process, and participation in plan development was perceived as more of an obligation than a priority [67] Nevertheless, according to an interview with the process managers, a significant amount of money $(\sim 1 \mathrm{M} €)$, was allocated for the participatory process.

In the Tucson AMA the Arizona Department of Water Resources, is responsible for the creation, review, and implementation of the AMA management plans. At the time of the Third Management Plan, the Tucson AMA had a local field staff, who were responsible for the planning process, however, none of the staff were dedicated only to managing the public engagement process and the members of the groundwater users advisory committee (GUAC) were not compensated for their time.

While explicit funding for the participatory process, as indicated in the Ebro River case, could be a reflection of a greater political leadership, our research did not indicate that political leadership was significant in either case.

\subsubsection{Social Awareness}

Historically, the Ebro Basin has a significant tradition of social movements fighting for an improved water management in the basin [68]. Huge public demonstrations, mostly related to building of dams and water transfers, have been organized in the last 20 years resulting in high media visibility and impact on water policies [69-71]. As a consequence, social awareness and an involvement of a significant number of people on water issues has occurred, creating a network of over one hundred 
of green social organizations along the basin. On the other hand, collaboration between environmental organizations and water authority has been almost non-existent, while the importance of irrigation uses in the basin has resulted in a close relationship between the sector and the water authority $[67,72]$. Implementation of the Water Framework Directive during the first planning cycle did, however, cause the RBO to try to open new paths for collaboration with all the stakeholders. Based on responses from interviewees, and the fact that no participatory activities at a basin or sub-basin level have been implemented after the first RBMP planning cycle, it seems that this path has been lost in the second planning cycle. Social movements initiated in the first planning cycle have, however, continued.

In Tucson, there is an active and involved water community that includes citizen advocates and water professionals from the private and public sectors. The region has a history of grassroots action on water issues [73,74]. In the 1990s, issues with the delivery of CAP water that caused brown water to flow from some resident's taps resulted in a citizen's initiative that restricts how CAP water is delivered to this day [75]. Most conflict in the basin has been centered around decisions to deliver CAP water and the use of reclaimed water, not the AMA management plans per se [76]. The community has a long-standing and strong water conservation ethic [76], and is focused primarily on collaboration with water managers. However, according to interviews, at the time of the Third Management Plan the environmental community was not involved in planning.

\subsection{The Participatory Process}

Among the different degrees of public participation mentioned previously (e.g., [9,10]), we will focus our analysis on the apparent degree of participation using the classifications proposed by Organization for the Economic Co-operation and Development (OECD) and the WFD in its guidance document on public participation [64], from which we identify the following degrees of participation: (1) Information: One-way relationship, where government produces and delivers information for use by the public; (2) Consultation: Two-way relationship, where government defines the issues for involvement, sets the questions, and manages the process; the public contributes with their views and opinions; (3) Active involvement, a partnership among government and the public, where the public is actively engaged in defining the process and content of policy-making, setting the agenda, and proposing policy options; the responsibility for the final decision rests with government. Taking into account this framework we review: the clarity of participation objectives; number and diversity of participants; number and duration of meetings; type of involvement and participatory methods used; and the visibility of the process.

\subsubsection{Ebro Basin}

The general aim of the Ebro's participatory process in the first water planning cycle after the approval of the WFD was to inform the general public about the planning process and its contents, and to collect possible metrics to be included in a potential program of measures. There was no commitment to include suggested measures in the final Ebro River management plan.

The quantity, quality, and access to information were significantly improved from previous planning efforts and provided: hydrographic information in digital and printed format, and a specific section of participatory process and related documents was created in the website of the RBO, including technical reports, meeting minutes and legal information. However, the reports prepared for the regional meetings were excessively technical, long, and were sent with insufficient time for review prior to the meetings. Interestingly, the index of transparency in water management in the Ebro Basin was considered to be up to $80 \%$ in 2011 , but has decreased to $60 \%$ in 2015 , when significant gaps on financial and economical information and information regarding relationships among the RBO and the citizens were identified [72]. These percentages coincide with moments of high participation (year 2011) and low participation (year 2015) in the planning cycle.

With regards to the consultation process, there were three different typologies of involvement: (1) formal periods for written comments (6 months for each consultation, 3 in total: timetable and work 
program for the production of the plan, overview of the significant water management issues in the river basin, draft of the river basin management plan, as is established in WFD); (2) institutional participation through Ebro's RBO Water Council (1 annual meeting, with 40 representatives of stakeholders in the basin) for making decisions about water planning; and (3) non-institutional or informal participation, through the implementation of an on-site participatory process. This process was organized between 2006 and 2008 (during 19 months) at the basin (17 meetings) and 27 sub-basins (107 meetings) levels. These meetings were organized with different sectors separately: social sector (environmental orgs, neighborhood orgs, educational orgs, recreational users); economic sector (irrigators, industry, etc.); administration sector (local councils, regional governments). The total number of participants was 1483, but only 172 participated in more than one meeting. Each meeting lasted for two hours, including a presentation by the basin authority and time afterwards for participant comments and proposals. Taking into account the little time for discussion and the absence of intersectorial debates, no opportunity for deliberation or opinion exchange was promoted, nor any actions for general public involvement. However, a diversity of stakeholders and water interests were represented in the meetings. Moreover, at basin scale, two bottom-up participatory processes were implemented, one with environmental sector, another with recreational users [64]. Both were proposed to the basin authority by the environmental community in one hand, and the recreational users on the other. These processes were supported and funded by the RBO and managed by independent consultants. They had a deliberative approach and can be identified as active involvement. These two participatory processes were considered best practices by interviewees.

The visibility of the planning and participatory processes have improved significantly as compared to previous planning processes, which were elaborated from within the confines of the governing board of the RBO. To date, however, the current process has only reached expert stakeholders, as the general public was not involved in the process and no active dissemination was promoted for them.

\subsubsection{Tucson AMA}

In the Tucson AMA, management plans provide a regulatory context and framework, or the rules of engagement, but they are not operational plans for the regulated water users in the region. Within this framework water companies and other regulated water users determine how they will meet these rules. The objective of public participation in the Third Management Plan was therefore to gain approval by the regulated community of the proposed framework and this objective was clearly outlined within the plan. It is notable, however, that Arizona statute $(\S 45-421(1))$ requires that the GUAC comment, but not approve the plan before it is promulgated. Therefore, there are no requirements for approval by the citizen body (the GUAC) or the public prior to adoption of the plan.

The creation of the Third Management Plan was between informational and consultational on the spectrum of participation. The plan was developed in three stages beginning in 1994 and culminated with adoption of the plan in 1999. Participatory methods used were meetings, public hearings, and written comments. The first stage of development was to collect and internally analyze data. These data were released for public review and comment through a "State of the AMA" report [77]. Issues identified in the report and raised by the community were addressed by the Department through a series of white papers that identified recommended alternatives. These alternatives were then formulated into program concepts and then the chapters within the plan. Public input through particularly the second and third stage of this process was via the GUAC and eight formal technical advisory committees in different subject areas relevant to the plan. The technical committees met on a regular basis for almost two years during the development of the plan. In total, there were 88 people involved representing a broad array of water management interests. In the opinion of some interviewees, however, the involvement of the advisory committees was mostly after management decisions have been made based on the agency research associated with the background technical report. 
The GUAC rejected the initial plan presented by the Department because it did not bring the Tucson AMA to safe-yield of the aquifer. Once the plan was released, public hearings where ADWR described and answered public questions on the plan were conducted to give an opportunity for public oral and written comments. The Department evaluated these comments and then issued a summary of the hearings and findings prior to the first-order for adoption for the plan. The final management plan was adopted in 1999. The majority of participation in the plan was in person.

Despite the assertion within the plan that "The Department [ADWR] philosophy is to maximize public input on the content of the management plans to ensure that the public's concerns and ideas are adequately incorporated", our interviews confirmed those of a previous review of AMA management plans by Megdal et al. [62] who found that overall the public process in this planning effort was insufficient. Trust between ADWR and the regulated community was of particular concern in our findings and that of Megdal et al. [62]. In their report Megdal et al. [62] suggest that the public participation process could be improved by "empowering (ADWR) planning staff so it is clear to stakeholders that they are influencing the decision-making process". It was also noted that ADWR's ability to engage with stakeholders is hampered by a lack of expertise and experience with the management plan process by current staff as a result of staff turnover. Like the Ebro River Basin process, the Third Management Plan was not visible to the general public, but did incorporate expert stakeholders that are impacted by the Plan, namely the regulated water community.

\subsubsection{Comparative Analysis}

With regards to the participation process, the cases appear very similar (Table 7), which is especially notable given the varied scales of the two case-study basins. A more in-depth review would undoubtedly show more differences, i.e., information to the public was further developed and systematically organized in the Ebro Basin (probably as a result of the WFD obligations), and the structure and participative procedures of the regional meetings and active involvement.

Table 7. Comparison of case studies' participatory processes.

\begin{tabular}{ccc}
\hline & Ebro Basin & Tucson Basin \\
\hline Clarity of Objectives & Yes & Yes \\
\hline Participants & 124 & 88/high diversity \\
\hline Meetings & Remote and in person & $\begin{array}{c}\text { Exact number not available, frequent } \\
\text { meetings over 2-years }\end{array}$ \\
\hline Participation & $\begin{array}{c}\text { Information, consultation and } \\
\text { active involvement (written } \\
\text { comments, institutional and non } \\
\text { institutional participation) }\end{array}$ & $\begin{array}{c}\text { Remote and in person } \\
\text { (written comments, institutional and } \\
\text { non institutional participation) }\end{array}$ \\
\hline Visibility & Low & Low \\
\hline
\end{tabular}

\subsection{Outcomes}

The outcomes of the participatory processes are examined against the impacts on public policy and elements of adaptive capacity building discussed previously in the methods. The impact on public policies is measured on the ability for the public to influence the final plan and adaptive-capacity building is measured based on seven indicators: learning, knowledge, collective vision, willingness, networks, trust, and continuity.

\subsubsection{Ebro Basin}

Regarding the impact on public policies, only a few measures proposed during the participation process were included in the plan, and no changes were made to the strategic vision of the plan. 
There is a general perception that stakeholder impact on policy does not depend on the quality of the process but rather on the limitations of management and political will. According to interviewees, the boundaries of negotiation and a mechanism for prioritizing management measures suggested during the participatory process need to be defined at the beginning of the process. Without these the process is considered to be inefficient. Nevertheless, the more optimistic interviewees noted that despite minimal impact on the final plan, the consultation process alone forced the agency to respond and justify with more details the contents of the plan, and in doing so improved the final contents of the plan.

In contrast to the influence of stakeholders on the final plan, interviewees identified considerable impact on adaptive capacity by the process. Engagement was seen as a learning process in both technical (i.e., planning cycle, the main issues in the Ebro Basin) and social aspects (i.e., stakeholder opinions, management of disagreements, how to participate), which also generated knowledge about the issues and new proposals for management. However, there was no transformation of private interests into a public position that incorporated a collective perspective, as evidenced by the fact that there was neither the time nor the space for a common discussion or deliberation among stakeholders, with the exception of the aforementioned participatory processes at basin scale promoted by the RBO with the environmental and recreational sectors.

The process has also increased stakeholder willingness to be involved in water issues and their collaboration with other groups. However, the fact that no participatory process has been promoted in the subsequent water planning cycles has caused frustration and a decrease in public involvement in water issues in the basin. Even so, two lasting groups emerged from the participatory process at the basin scale: Cuenca Azul (network of the environmental sector), and AURA (association of recreation users). The first is still active, while the second exists but is not currently active. Furthermore, the process improved coordination within the existing groups. At sub-basin scale, the participatory process was not conducive to the emergence of lasting groups or the promotion of coordination among stakeholders, as no deliberation and no multi-sectoral meetings were held, and most of the time, participants only attended one meeting, as there were no other opportunities to meet. Along the same lines, trust was built among members of the same sector but not across different stakeholder groups. According to the interviewees responses, the absence of deliberation and the insufficient time and opportunities to meet have been identified as one of the weakness of the process, while the creation of close relationships among stakeholders and water agency is considered one of its positive results.

As previously noted, most of the impacts on adaptive capacity building are attributed to informal and on-site participation processes. In the following planning cycle participation was relegated to the formal periods for written comments and participation in the Water Council. As one of the key elements of adaptive capacity building is the continuity in time, presumably, the gaps in opportunities for participation in the forthcoming plans will involve that adaptive capacity will not be maintained in the future at current levels.

\subsubsection{Tucson AMA}

As described by one interviewee, the Third Management Plan was the result of a "decide, present, defend" approach to public participation. In contrast, more recent water planning efforts in the region, led by the City of Tucson and Tucson Water, have been more of a bottom-up process and incorporated public, or at least key stakeholder information from the outset. While ADWR made an effort to respond to comments and suggestions collected during the process, this participation does not appear to have had a significant impact on the final plan per se. Subsequent litigation over plan requirements for municipal water use reductions (gallons per capita per day (GPCD) program) has, however, made changes the Tucson AMA Third Management Plan. The dispute over the GPCD program did not resolve until 2004 and it was not until 2008 when the plan was changed as a result of the litigation.

It is unclear through the interviews if the process of creating the Third Management Plan was a learning process overall. From the standpoint of collection and dissemination of data to the working 
groups it was a learning process, however, whether or not ADWR learned from the stakeholders and/or the stakeholders learned from the Department is unclear. Similar to the Ebro River Basin experience the process had an impact on communication among water groups as it resulted in the formation of a new community-led group, the Safe-Yield Task Force. Different from the Ebro Basin experience, however, the community-led group is broad based, not just among environmental or recreational interests. The Safe-Yield Task Force was a direct result of stakeholders concern that the working group and GUAC models of participation were not sufficient to address the local concerns about maintaining (and improving) aquifer water levels. The overall process appears to be adequate at incorporating the thoughts of the regulated community, it did not, however, include the general public in any meaningful way, as it is not necessarily intended to, and certainly not required to be, a public process. Interviewees noted that during the Third Management Plan time trust between ADWR and the public was relatively low. This trust has increased overtime, as perhaps indicated by the disbanding of the Safe-Yield task force in the mid-2000s. This group did, however, come together again after a period of almost 10 years as ADWR began the Fourth Management Plan process. It is unclear if the process impacted stakeholder's willingness to be involved in water issues or changed participant perspectives on key issues, but given the robust engagement seen in Tucson today it does not appear, at the very least, to have hindered involvement. Finally, there is no evidence that the final plan incorporated collective perspectives gathered from interactions among the different stakeholders and the Department.

Current planning efforts under the Fourth Management Plan, which should have been released almost five years ago, has taken more of a bottom-up approach, however, the plan still lacks a mechanism for input beyond the GUAC. As noted above, the safe-yield taskforce, created out of frustration with the Third Management Plan public input process, had stopped meeting for a period of almost 10 years, and then re-started in late 2008 in response again to frustrations with the timeliness of the Fourth management plan and concerns over ADWR capacity. One interviewee noted frustration with the participation process in the Fourth management plan because it has been under development for so long and has not been widely discussed. This person noted, however, that while opportunities for participation and input have been slight, ADWR has been straightforward about their intentions to not make significant changes from the Third Management Plan and to not have public participation outside of GUAC meetings. It should also be recognized that during the Third Management Plan ADWR had a staff of over 10 people, physically located in Tucson, dedicated to creating the plan (although not necessarily dedicated to public engagement). For the Fourth management plan there is no one person dedicated to the Tucson management plan alone and all staff are in Phoenix. In other words, operational (person) capital has been severely weakened, as has leadership capital.

\subsubsection{Comparative Analysis}

The impacts of public participation on public policies and indicators of adaptive capacity are similar across the case studies (Table 8). In both of them only minor revisions to the plans occurred as a result of public input during the process. In the case of the Tucson AMA, major revisions to the plan were made after the promulgation of the plan as a result of a lawsuit, which suggests a failure of the participation process to address stakeholder concerns. In the case of the Ebro, more than 3000 proposals were incorporated in a "potential measures" document, but just a few of them were finally contemplated in the resultant Basin Management Plan.

With regards to adaptive capacity, both processes increased knowledge of the physical system and stakeholder concerns, encouraged willingness to be involved, and contributed to the creation of lasting groups which have served to increase the mechanisms for engagement in water management. 
Table 8. Impacts of public participation on public policies and adaptive capacity.

\begin{tabular}{|c|c|c|c|c|}
\hline \multirow[t]{2}{*}{ Impact } & \multicolumn{2}{|c|}{ Ebro } & \multicolumn{2}{|c|}{ Tucson } \\
\hline & Yes & No & Yes & No \\
\hline \multicolumn{5}{|c|}{ Public policies } \\
\hline Minor revisions & $x$ & & $x$ & \\
\hline Major revisions & & $x$ & & $x$ \\
\hline \multicolumn{5}{|c|}{ Adaptive capacity } \\
\hline Learning & $x$ & & & \\
\hline New knowledge & $x$ & & $X$ & \\
\hline Collective vision & & $x$ & & $x$ \\
\hline Willingness to be involved & $x$ & & $X$ & \\
\hline Lasting groups & $x$ & & $x$ & \\
\hline Trust & $x$ & & & $x$ \\
\hline Continuity & & $x$ & & $x$ \\
\hline
\end{tabular}

In interviews for the Tucson AMA some participants felt that learning occurred, while others felt strongly that it did not: It is, therefore, unclear if learning actually occurred. This result is intriguing given the length of engagement (over two years) that would seem to be sufficient for learning to occur. Interviewees for the Ebro, on the other hand, did indicate that learning had occurred and that trust had increased. The feeling that trust was not increased in the Tucson process could be due to the low levels of antecedent trust indicated by interviews or because the process did not appear to successfully incorporate stakeholder perspectives. Finally, neither of the case study processes achieved a collective vision through the process. This indicator is frequently linked to deliberation [78]. Thus, it is probable that by improving deliberation, a common public perspective will be an outcome of the participatory processes.

\section{Discussion}

The aforementioned conditions established by Blanco and Ballester [36] (political leadership, holistic approach, highly visible process, significant citizen impact on policies or a real cultural change) for achieving the "transformational capacity" of participation processes were largely absent in the case studies. According to the authors, without these conditions the benefits of participation should not be significant. However, some changes to the basin management plans and social adaptive capacity have been identified in our research as a result of both participatory processes.

Presumably, higher impacts would have been achieved if the conditions of "transformational capacity" were present, but it appears that they are not a necessary condition for change per se, but rather for achieving a higher degree of transformation.

\subsection{Role of the Context in Influencing Participatory Process and Its Outcomes}

Despite the more developed participatory legal framework for water management in Europe, the impact of the participatory process is similar in both case studies (Table 6). This may indicate that a higher democratic culture in Tucson case is compensating for its less developed participatory legal framework. On the other hand, the mere existence of a participatory legal framework guarantees the development of a participatory process, and therefore the beginning of a more or less productive interaction between the public and regulators, which otherwise would not have taken place in a context of less a democratic culture, such as in the Ebro Basin.

To date there have been no specific guidelines on implementing a participatory process in either case. While this provides flexibility in approach, it also enables a broad interpretation of the regulatory framework and disparate implementation under the same regulatory context. Less ambiguous legislation or rules on the features of the participatory processes could improve their design, development, and impacts [79]. For example, in the case studies stakeholder feedback was 
primarily carried out through written comments because of the legal obligation to respond them. This did not happen with the other types of consultation, such as the informal participation in the Ebro Basin.

Regarding the political leadership and the impact of participation on public policies, interviewees of both case studies have identified a direct relation between these two elements, which is consistent with other studies [37]. In fact, we would argue that the absence of political leadership is likely one of the most important reasons for the minimal impact of participatory processes in the Ebro and Tucson basins on the final basin management plans.

The Tucson and Ebro experiences, however, demonstrate how a lack of political leadership can be a starting point for the emergence of effective and grass-roots participation that increases stakeholder capacity to influence public policy. This is so for social movements regarding water management in the Ebro River Basin and their successes [79], but also the rise of social capital around water management in Tucson Basin through groups like the Safe-Yield Task Force. Both demonstrate the value of connections created as a result of lack of political leadership and an unsatisfactory public participation processes.

Finally, high levels of social awareness in both case studies have significantly influenced the outcomes of the participatory process. In the Ebro Basin in particular, social awareness led to additional capacity to exert political pressure and have an impact on mass media, therefore increasing visibility of the process. This increased awareness and visibility resulted in a broader set of informed stakeholders and increased technical capacity to participate, which enabled a deeper understanding of the issues and the creation of new knowledge.

Social awareness can also influence a participatory process' design and development (i.e., the creation of two ad-hoc participatory processes demanded by environmental and recreation users in the Ebro Basin). It can also guarantee of continuity of public involvement in water policies. Although the Safe-Yield Task Force in Tucson did not meet for almost a decade, the foundation laid in the late 1990s allowed it to reform when needed for the current planning effort. This group and the environmental network of the Cuenca Azul also prove how social awareness encourages the continuity required by adaptive capacity building.

Beyond the influence of social awareness on participation processes outcomes, it is interesting to observe that social awareness can manifest in different ways: a "reactive way" in the Ebro Basin (i.e., public demonstrations and demands), and a "collaborative way" in the Tucson Basin (i.e., inclusive approach through dialogue with stakeholders). While we do not have empirical data here to analyze the effectiveness of either approach, others have found that collaborative methods usually have better long-term results [80].

\subsection{Influence of the Participatory Process' Features in Its Outcomes}

There is a significant body of literature outlining ideal features of a participatory process (e.g., $[1,81,82])$. Of all the factors identified, two appear to be most salient to the results in our case studies: the existence of an active and on-site consultation process and that of deliberation. Even though neither of the participation processes had a meaningful impact on public policies, both had a significant influence on adaptive capacity. While adaptive capacity can also be achieved through other consultation means (e.g., online consultation, written comments) it is not to the degree and/or depth encouraged by the mentioned factors in our case studies (e.g., deeper social learning, additional knowledge, more and stronger networks, and more intense exchange of opinions).

Another question emerging from our case-study comparison is related to the continuity of the processes, which is a key component in maintaining adaptive capacity and encouraging social learning. In both cases there has been minimal effort to continue engagement efforts after the participation processes presented in our study and participation mechanisms are currently relegated to formal consultations through written comments and institutional participation. While in the case of the Tucson Basin this is certainly driven in part by the funding cuts made to ADWR in the late 2000s, in both basins the economic crisis is not the sole determining factor. 
The lack of continuity has been justified in the Ebro case because of the high human and financial expense and the significant time needed for organization of the participation process. New social innovation mechanisms and resources, such as online applications and networks that permit remote participation by stakeholders, can be implemented to reduce these costs and facilitate participation $[83,84]$. These methods should not be seen as a substitute for in-person consultation and deliberation, however, a combination of approaches is increasingly necessary to ensure a more effective and wider participation. While this is true for large basins like Ebro where the costs of travel and organizing events across the geography is resource intensive, it also applies to smaller basins like Tucson where there are no longer regional offices and the conveners, in this case ADWR, must travel to hold in-person meetings.

\section{Conclusions}

Stakeholder engagement is essential for effective and adaptive water management; however, the determinants of effective public participation are not well understood. In the case studies outlined here, we found that the influence of a participatory process on public water policies is mainly determined by the context of the process, i.e., legal framework, political leadership, and social awareness, whereas ability of a process to build adaptive capacity depends upon how the engagement process is implemented, in particular the existence of active on-site consultation and deliberation.

Acknowledgments: Funding for this research was provided by the University of Seville in the context of SWAN_Sustainable Water Action Project (FP 7 Grant Agreement: INCO-20011-7.6) (Alba Ballester) and the Arizona Technology and Research Initiative Fund (Kelly Mott Lacroix).

Author Contributions: Alba Ballester and Kelly Mott Lacroix conceived and designed the approach to this article, analysis of documents and interviews from their respective case studies, and co-wrote the paper.

Conflicts of Interest: The authors declare no conflict of interest.

\section{References and Notes}

1. The Organisation for Economic Co-operation and Development (OECD). Stakeholder Engagement for Inclusive Water Governance, OECD Studies on Water; OECD Publishing: Paris, France, 2015.

2. Lennox, J.; Proctor, W.; Russell, S. Structuring stakeholder participation in New Zealand's water resource governance. Ecol. Econ. 2011, 70, 1381-1394. [CrossRef]

3. Antunes, P.; Kallis, G.; Videira, N.; Santos, R. Participation and evaluation for sustainable river basin governance. Ecol. Econ. 2009, 68, 931-939. [CrossRef]

4. Río Declaration. Río Declaration on Environment and Development; ONU Doc. A/CONF. 151/5/Rev.1; ONU: Río de Janeiro, Brasil, 1992.

5. United Nations Economic Commission for Europe (UNECE). Aarhus Convention on Access to Information, Public Participation in Decision-making and Access to Justice in Environmental Matters; UNECE: Aarhus, Denmark, 1998.

6. Directive 2000/60/EC of the European Parliament and of the Council of 23 October 2000 establishing a framework for Community action in the field of water policy.

7. Directive 2001/42/EC of the European Parliament and of the Council of 27 June 2001 on the assessment of the effects of certain plans and programmes on the environment.

8. Ballester, A.; Subirats, J. Nuevos enfoques institucionales en la gestión del agua. Directiva Marco del Agua: Participación pública y gestión de conflictos. In El Agua: Perspectiva Ecosistémica y Gestión Integrada de Aguas; Fundación Nueva Cultura del Agua: Zaragoza, Spain, 2015; Available online: http://fnca.eu/biblioteca-delagua/directorio/file/2767?search=1 (accessed on 21 June 2016).

9. Arnstein, S.R. A Ladder of Citizen Participation. J. Am. Inst. Plan. 1969, 35, 216-224. [CrossRef]

10. International Association for Public Participation. Spectrum of Public Participation. 2007. Available online: http://c.ymcdn.com/sites/www.iap2.org/resource/resmgr/imported/IAP2\%20Spectrum_vertical. pdf (accessed on 19 February 2016).

11. Putnam, R.D. Bowling Alone: Americas Declining Social Capital; Aula: Budapest, Hungary, 2006; pp. $207-219$.

12. Reed, M.S. Stakeholder participation for environmental management: A literature review. Biol. Conserv. 2008, 141, 2417-2431. [CrossRef] 
13. Bal, M.; Bryde, D.; Fearon, D.; Ochieng, E. Stakeholder Engagement: Achieving Sustainability in the Construction Sector. Sustainability 2013, 5, 695-710. [CrossRef]

14. Garin, P.; Rinaudo, J.D.; Ruhlmann, J. Linking expert evaluations with public consultation to design water policy at the watershed level. Water Sci. Technol. 2002, 46, 263-271. [PubMed]

15. Barraqué, B.; Le Bourthis, J.P.; Maurel, P.; Raymond, R. Public Participation in the Dordogne River Basin; Case study report produced under work package 5 of the HarmoniCOP project. LATTS-CNRS; Sorbonne University \& CEMAGREF: Paris, France, 2004.

16. Christenson, J.A.; Robinson, J.W., Jr. In search of community development. In Community Development in America; Iowa State University Press: Ames, IA, USA, 1980; pp. 3-17.

17. Chase, L.C.; Decker, D.J.; Lauber, T.B. Public participation in wildlife management: What do stakeholders want? Soc. Nat. Res. 2004, 17, 629-639. [CrossRef]

18. Ballester, A.; Pares, M. Democracia deliberativa y política de agua. In Experiencias de Participación en el Contexto de la Directiva Marco del Agua en España; Congreso de Gestión y Planificación de Agua: Lisboa, Portugal, 2013.

19. Garmendia, E.; Stagl, S. Public participation for sustainability and social learning: Concepts and lessons from three case studies in Europe. Ecol. Econ. 2010, 69, 1712-1722. [CrossRef]

20. Tippett, J.; Searle, B.; Pahl-Wostl, C.; Rees, Y. Social learning in public participation in river basin management-early findings from HarmoniCOP European case studies. Environ. Sci. Policy 2005, 8, 287-299. [CrossRef]

21. Mosert, E.; Craps, M.; Pahl-Wostl, C. Social learning: The key to integrated water resources management? Water Int. 2008, 33, 293-304. [CrossRef]

22. Monroe, M.; Plate, R.; Oxarart, A. Intermediate collaborative adaptive management strategies build stakeholder capacity. Ecol. Soc. 2013, 18, 24. [CrossRef]

23. Jolibert, C.; Wesselink, A. Research impacts and impact on research in biodiversity conservation: The influence of stakeholder engagement. Environ. Sci. Policy 2012, 22, 100-111. [CrossRef]

24. Innes, J.E.; Booher, D.E. Reframing public participation: Strategies for the 21st century. Plan. Theory Pract. 2004, 5, 419-436. [CrossRef]

25. Muro, M.; Jeffrey, P. Time to Talk? How the Structure of Dialog Processes Shapes Stakeholder Learning in Participatory Water Resources Management. Ecol. Soc. 2012, 17. [CrossRef]

26. Pelling, M. Learning from others: Scope and challenges for participatory disaster risk assessment. Disasters 2007, 31, 373-385. [CrossRef] [PubMed]

27. Bankoff, G.; Frerks, G.; Hilhorst, D. Mapping Vulnerability: Disasters, Development and People; Earthscan: London, UK, 2004.

28. Walker, G.B.; Senecah, S.L.; Daniels, S.E. From the forest to the river: Citizens' views of stakeholder engagement. Hum. Ecol. Rev. 2006, 13, 193.

29. Burton, P. Conceptual, Theoretical and Practical Issues in Measuring the Benefits of Public Participation. Evaluation 2009, 15, 263-284. [CrossRef]

30. Newig, J.; Günther, D.; Pahl-Wostl, C. Synapses in the network: Learning in governance networks in the context of environmental management. Ecol. Soc. 2010, 15, 24.

31. Mott Lacroix, K.E.; Xiu, B.C.; Megdal, S.B. Building Common Ground for Environmental Flows using Traditional Techniques and Novel Engagement Approaches. Environ. Manag. 2016, 57, 912-928. [CrossRef] [PubMed]

32. Hermans, F.L.P.; Haarmann, W.M.F.; Dagevos, J.F.L.M.M. Evaluation of stakeholder participation in monitoring regional sustainable development. Reg. Environ. Chang. 2011, 11, 805-815. [CrossRef]

33. Booth, A.; Halseth, G. Why the public thinks natural resources public participation processes fail: A case study of British Columbia communities. Land Use Policy 2011, 28, 898-906. [CrossRef]

34. Blanco, I.; Ballester, M. Participar para transformar? La experiencia de los Presupuestos Participativos en la provincia de Barcelona. Gest. Anál. Políticas Públicas 2011, 5, 117-144.

35. Haus, M.; Heinel, H.Y.; Stewart, M. Introduction. In Urban Gover Nance and Democracy: Leadership and Community Involvement; Londres: Routledge, UK, 2005.

36. Wagenaar, H. Governance, complexity and democratic participation: How citizens and public officials harness the complexities of neighbourhood decline. Am. Rev. Public Adm. 2007, 37, 17-50. [CrossRef]

37. Font, J.; Blanco, I. Polis, la Ciudad Participativa; Diputació de Barcelona: Barcelona, Spain, 2006. 
38. Fung, A. Varieties of Participation in Complex Governance. Public Adm. Rev. 2006, 66, 66-75. [CrossRef]

39. Brugué, Q. Modernizar la administración desde la izquierda: Burocracia, nueva gestión pública y administración deliberativa. Rev. CLAD Reforma Democr. 2004, 29, 1-16.

40. Subirats, J. Elementos de Nueva Política; Centro de Cultura Contemporánea de Barcelona: Barcelona, Spain, 2003.

41. Brooks, N.; Adger, W.N.; Kelly, P.M. The determinants of vulnerability and adaptive capacity at the national level and the implications for adaptation. Glob. Environ. Chang. 2005, 15, 151-163. [CrossRef]

42. Jones, L.; Ludi, E.; Levine, S. Towards a Characterization of Adaptive Capacity: A Framework for Analysing Adaptive Capacity at Local Level. Overseas Development Institute. 2010. Available online: https://goo.gl/CRvNsd (accessed on 21 June 2016).

43. Eakin, H.; Lemos, M.C. Adaptation and the state: Latin America and the challenge of capacity-building under globalization. Glob. Environ. Chang. 2006, 16, 7-18. [CrossRef]

44. Hobson, K.; Niemeyer, S. Public responses to climate change: The role of deliberation in building capacity for adaptive action. Glob. Environ. Chang. 2011, 21, 957-971. [CrossRef]

45. Lockwood, M.; Raymond, C.; Oczkowski, E.; Morrison, M. Measuring the dimensions of adaptive capacity: A psychometric approach. Ecol. Soc. 2015, 20, 37. [CrossRef]

46. Robinson, L.; Berkes, F. Multi-level participation for building adaptive capacity: Formal agency-community interactions in northern Kenya. Glob. Environ. Chang. 2011, 21, 1185-1194. [CrossRef]

47. Emerson, K.; Gerlak, A. Adaptation in collaborative governance regimes. Environ. Manag. 2014, 54, 768-781. [CrossRef] [PubMed]

48. Pahl-Wostl, C.; Craps, M.; Dewulf, A.; Mostert, E.; Tabara, D.; Taillieu, T. Social learning and water resources management. Ecol. Soc. 2007, 12, 5.

49. Olsson, P.; Folke, C.; Berkes, F. Adaptive co-management for building resilience in social-ecological systems. Environ. Manag. 2004, 34, 75-90. [CrossRef] [PubMed]

50. Hagmann, J.; Chuma, E. Enhancing the Adaptive Capacity of the Resource Users in Natural Resource Management. Agric. Syst. 2002, 73, 23-39. [CrossRef]

51. Adger, W.N. Social Aspects of Adaptive Capacity. In Climate Change, Adaptive Capacity and Development; Smith, J.B., Klein, R.J., Eds.; Imperial College Press: London, UK, 2003; pp. 29-50.

52. Gupta, J.; Termeer, C.; Klostermann, J.; Meijerink, S.; Van den Brink, M.; Jong, P.; Nooteboom, S.; Bergsma, E. The adaptive capacity wheel: A method to assess the inherent characteristics of institutions to enable the adaptive capacity of society. Environ. Sci. Policy 2010, 13, 459-471. [CrossRef]

53. Pahl-Wostl, C.; Newig, J.; Ridder, D. Linking public participation to adaptive management. In Groundwater Science \& Policy: An International Overview; Quevauviller, P., Ed.; Springer: Berlin, Germany, 2008; pp. 150-173.

54. Tompkins, E.L. Successful adaptation to climate change across scales. Glob. Environ. Chang. 2005, 15, 77-86.

55. Engle, N.; Lemos, M.C. Unpacking governance: Building adaptive capacity to climate change of river basins in Brazil. Glob. Environ. Chang. 2010, 20, 4-13. [CrossRef]

56. Confederación Hidrográfica del Ebro. Plan Hidrológico de la Cuenca del Ebro; Ministerio de Medio Ambiente: Madrid, Spain, 2014.

57. Webb, R.H.; Betancourt, J.L.; Johnson, R.R.; Turner, R.M. Requiem for the Santa Cruz: An Environmental History of an Arizona River; University of Arizona Press: Tucson, AZ, USA, 2014.

58. Overpeck, J.; Udall, B. Dry Times Ahead. Sci. Signal. 2010, 328, 1641. [CrossRef] [PubMed]

59. Marshall, R.M.; Robles, M.D.; Majka, D.R.; Haney, J.A. Sustainable Water Management in the Southwestern United States: Reality or Rhetoric? PLoS ONE 2010, 5. [CrossRef] [PubMed]

60. Arizona Department of Water Resources. Personal Communication with Michelle Moreno; Public Information Officer: Phoenix, AZ, USA, 2015.

61. Ballester, A.; La Calle, A.; Subirats, J.; Espluga, J. Participación pública en la demarcación hidrográfica del Ebro. In Proceedings of the VI Congreso Ibérico de Gestión y Planificación del Agua, Vitoria, Spain, 4-7 December 2008.

62. Megdal, S.; Zachary Smith, A.; Lien, A. Evolution and Evaluation of the Active Management Area Management Plans; University of Arizona Water Resources Research Center: Tucson, AZ, USA, 2008.

63. Rabelo, D.; Espluga, J.; Edmilson, C.; Brugué, Q. Citizenship participation in water management plans in the Doce River Basin, Brazil and Catalonia, Spain. Water Policy 2014, 16, 205-221. [CrossRef] 
64. European Commission. Guidance on Public Participation in Relation to the Water Framework Directive; Office for Official Publications of the European Communities: Luxembourg, Luxembourg, 2003.

65. Arizona Department of Water Resources (ADWR). Tucson Active Management Area-Third Management Plan; ADWR: Phoenix, AZ, USA, 1999.

66. Jacobs, K.L.; James, M.H. Managing for Sustainability in an Arid Climate: Lessons Learned from 20 Years of Groundwater Management in Arizona, USA. Hydrogeol. J. 2004, 12, 52-65. [CrossRef]

67. Ballester, A. Análisis de Las Entrevistas Realizadas en Relación Con el Proceso de Participación Asociado a la Elaboración del Plan Hidrológico de la Demarcación Hidrográfica del Ebro. PART-DMA Project Unpublished Report. 2012. Available online: http://blogs.uab.cat/partdma/documentacion/ (accessed on 20 February 2016).

68. Ballester, A.; Ferrer, G. Conflictividad en la Gestión Hídrica. Guía Nueva Cultura del Agua: Una Guía de Referencia y Consulta Sobre la Gestión y Conservación de Los Recursos Hídricos en España, Fundación Nueva Cultura del Agua. 2012. Available online: http://www.fnca.eu/guia-nueva-cultura-del-agua/ (accessed on 20 February 2016).

69. Parés, M. River basin management planning with participation in Europe: From contested hydro-politics to governance-beyond-the-state. Eur. Plan. Stud. 2011, 19, 457-478. [CrossRef]

70. Arrojo, P.; Casajús, L.; Copitzy, A. La Rebelión de la Montaña: Los Conflictos del Agua en Aragón; Bakeaz Centro Documentación Estudios Para La Paz: Bilbao, Spain, 2010.

71. Casademunt, A.; Alfama, E.; Coll, G.; Cruz, H.; Martí, M. Per Una Nova Cultura del Territorio; Icaria, Antrazyt: Barcelona, Spain, 2007.

72. Transparency International España. Índice de Transparencia en la Gestión del Agua (INTRAG). 2015. Available online: http://transparencia.org.es/intrag-2015/ (accessed on 19 February 2016).

73. Logan, M.F. The Lessening Stream: An Environmental History of the Santa Cruz River; University of Arizona Press: Tucson, AZ, USA, 2002.

74. Tarlock, A.D.; Van de Wetering, S.B. Water and western growth. Am. Plan. Assoc. Plan. Environ. Law 2007, 59, 3-13. [CrossRef]

75. Megdal, S.B.; Forrest, A. How a Drought-Resilient Water Delivery System Rose Out of the Desert: The Case of Tucson Water. J. Am. Water Works Assoc. 2015, 107, 46-52. [CrossRef]

76. Akhter, M.; Ormerod, K.J.; Scott, C.A. Lost in translation: Resilience, social agency, and water planning in Tucson, Arizona. Crit. Plan. 2010, 17, 47-65.

77. Arizona Department of Water Resources. State of the AMA: Tucson Active Management Area; Arizona Department of Water Resources: Phoenix, AZ, USA, 1996.

78. Gutmann, A.Y.; Thompson, D. Why Deliberative Democracy; Princeton University Press: Princeton, NY, USA, 2004.

79. De Stefano, L. Facing the Water Framework Directive challenges: A baseline of stakeholder participation in the European Union. J. Environ. Manag. 2010, 91, 1332-1340. [CrossRef] [PubMed]

80. Ridder, D.; Mostert, E.; Cernesson, F.; HarmonyCop Team. Learning Together to Manage Together: Improving Participation in Water Management; University of Osnabrück: Osnabrück, Germany, 2005.

81. Mott Lacroix, K.E.; Megdal, S.B. Explore, Synthesize, and Repeat: Unravelling Complex Water Management Issues through the Stakeholder Engagement Wheel. Water 2016, 8. [CrossRef]

82. Jeffery, N. Stakeholder Engagement: A Road Map to Meaningful Engagement; Doughty Centre, Cranfield University School of Management: Cranfield, UK, 2009.

83. Sarzynski, A. Public participation, civic capacity, and climate change adaptation in cities. Urban Clim. 2015, 14, 52-67. [CrossRef]

84. Hernandez-Mora, N.; Cabello, V.; De Stefano, L.; Del Moral, L. Networked water citizen organizations in Spain: Potential for transformation of existing power structures in water management. Water Altern. 2015, 8 , 99-124.

(C) 2016 by the authors; licensee MDPI, Basel, Switzerland. This article is an open access article distributed under the terms and conditions of the Creative Commons Attribution (CC-BY) license (http://creativecommons.org/licenses/by/4.0/). 